\title{
VOLUME 21 NUMBER 2
}

JUNE 1988

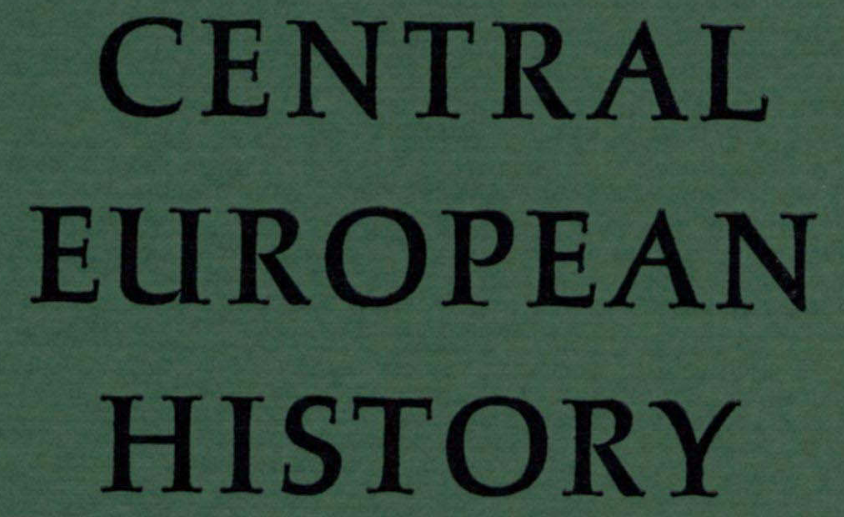

Sponsored by the

Conference Group for Central European History of the American Historical Association

\author{
PUBLISHED QUARTERLY BY \\ EMORY UNIVERSITY
}




\section{EDITORIAL POLICY}

Central European History publishes articles, bibliographical articles, review articles, and reviews dealing with the history of German-speaking Central Europe. Manuscripts are solicited using all approaches to history, and dealing with all historical periods. Because space is limited, articles which have been or soon will be published elsewhere are not accepted, nor are translations of such articles. Unsolicited book reviews are not accepted. Authors who desire to prepare bibliographical articles are urged to communicate with the editors first. Manuscripts and correspondence should be directed to:

\section{Central European History \\ Emory University \\ Atlanta, Georgia 30322}

The entire text, including footnotes, of manuscripts submitted for publication must be prepared in double-spaced typescript, with generous margins to allow for copy-editing. Footnotes should be numbered consecutively, and should be placed in a separate section at the end of the text. It has become essential to require two copies of manuscripts, to expedite editorial evaluation and to guard against loss in the mails.

The subscription rates for Central European History for the United States and possessions are as follows (note that individual rates include $\$ 6$ per year dues to the Conference Group for Central European History):

$\begin{array}{lcc} & \text { INDIVIDUALS } & \text { InSTITUTIONS } \\ 1 \text { year } & \$ 22 & \$ 32 \\ 2 \text { years } & \$ 42 & \$ 62 \\ 3 \text { years } & \$ 60 & \$ 90\end{array}$

Student and emeritus rate $\$ 7$ per year.

For all other countries add $\$ 3.00$ per year for mailing. Subscriptions are for calendar year only.

Back issues: All back volumes, starting with Volume I (1968), are available at $\$ 22$ for individuals, $\$ 32$ for institutions, plus $\$ 1$ per volume for mailing. For student and emeritus prices, and for single issues, please inquire.

Address: Central European History, Emory University, Atlanta, Georgia 30322. 


\section{CENTRAL EUROPEAN HISTORY}

\section{ARTICLES}

The Persecution of Witches as Restoration of Order:

The Case of Germany, I 590s-I650s

BY HARTMUT LEHMANN

The Thirty Years' War, the "General Crisis," and the

Origins of a Standing Professional Army in the

Habsburg Monarchy

BY JOHN A. MEARS

Edgar Julius Jung: The Conservative Revolution in Theory and Practice

BY LARRY EUGENE JONES

\section{SUGGESTIONS AND DEBATES}

The Leadership and Structure of the Tauber Band

during the Peasants' War in Franconia

BY ROY L. VICE 


\title{
CENTRAL EUROPEAN HISTORY
}

ISSN $0008-9389$

\author{
Sponsored by the Conference Group for Central European History \\ of the American Historical Association \\ Published quarterly by Emory University, Atlanta, Georgia 30322
}

\section{BOARD OF EDITORS}

\author{
MARGARET LAVINIA ANDERSON MICHAEL H. KATER \\ Swarthmore College \\ THOMAS A. BRADY \\ York University \\ University of Oregon \\ CHARLES E. MCCLELLAND \\ University of New Mexico \\ JOHN GIMBEL \\ Humboldt State University \\ JEAN H. QUATAERT \\ LARRY EUGENE JONES \\ Canisius College \\ State University of New York, Binghamton \\ KARL A. ROIDER, JR. \\ Louisiana State University
}

GARY D. STARK

University of Texas at Arlington

\section{Editor}

DOUGLAS A. UNFUG

Emory University

Associate Editor

JAMES VAN HORN MELTON

Emory University

Consulting Editors

DAVID W. HENDON THEODOR V. BRODEK

Baylor University

$$
\begin{array}{ll}
\text { Business Manager } & \text { Copy Editor } \\
\text { JUANITA STITT } & \text { GLEE UNFUG }
\end{array}
$$

All correspondence should be sent to Central European History, Emory University, Atlanta, Georgia 30322. $\$$ Subscription rates, U.S. and possessions: Individuals (including $\$ 6$ per year dues) I year $\$ 22$ (U.S.), 2 years $\$ 42,3$ years $\$ 60$. Student and emeritus rate $\$ 7$ a year. Single copies $\$ 6$ (double issues $\$ 12$ ), including postage. $\$$ Institutions I year $\$ 32,2$ years $\$ 62$, 3 years $\$ 90$. Single copies $\$ 8$ (double issues $\$ 16$ ), including postage. $\$$ All other countries: Add $\$ 3.00$ per year (\$I. 50 per single or double issue) for mailing. $\$$ Subscriptions by calendar year only $\$$ Individual subscriptions include membership in the Conference Group for Central European History. All subscriptions postpaid. Checks should be made out to Central European History. $\Phi$ Published quarterly in March, June, September, and December. $\square$ Central European History is indexed or abstracted in Historical Abstracts, Humanities Index, Book Review Index, Intemationale Bibliographie der Zeitschriftenliteratur (IBZ), Current Contents / Social and Behavioral Science, Social Sciences Citation Index, Universal Reference System, and Combined Retrospective Index Sets in History (CRIS). \$Copyright $\bigcirc$ I 990 by Emory University. All rights reserved. $\$$ Printed by MeridenStinehour Press, Lunenburg, Vermont. 